\title{
DETERMINING THE CHEMICAL COMPOSITION AND NUTRITION QUALITY OF HUNGARIAN VETCH SILAGE (VICIA PANNONICA CRANTZ) MIXED WITH WHEAT (TRITICUM AESTIVUM L.) AND BARLEY (HORDEUM VULGARE L.) AT DIFFERENT RATES
}

\author{
TURAN, N. \\ Department of Field Crops, Faculty of Agriculture, Siirt University, Siirt, Turkey \\ (e-mail: nturan49@siirt.edu.tr; phone: +90-484-212-1111; fax: +90-484-223-1998) \\ (Received 23 ${ }^{\text {rd }}$ Sep 2019; accepted 30 ${ }^{\text {th }}$ Jan 2020)
}

\begin{abstract}
This research was carried out to determine the quality values of Hungarian vetch silage mixed with wheat and barley grown in winter under the ecological conditions of Eastern Anatolia region, Turkey in the 2017-2018 growing season. To determine the quality values and chemical composition of the silage mixtures obtained from the different of Hungarian vetch, wheat and barley it was prepared as three replications and filled in 2-L jars and then firmly suppressed and tightly closed so that they do not breathe. The mixture rates of Hungarian vetch $(\mathrm{HV})$, wheat $(\mathrm{W})$ and barley $(\mathrm{B})$, their pure sowed were $80 \%, 60 \%, 40 \%, 20 \%$ of B $+20 \%, 40 \%, 60 \%, 80 \%$ of HV $+80 \%, 60 \%, 40 \%, 20 \%$ of W. Silage jars were opened after 60 days and $\mathrm{pH}$ value, acid detergent fiber ( $\mathrm{ADF}$ ), neutral detergent fiber (NDF), crude protein content and organic acid values and some macro element contents were measured. The values for ADF, NDF, digestible dry matter (DDM), dry matter intake (DMI), relative feed value (RFV), dry matter (DM), crude protein (CP) of silages were $28.57-41.65 \%, 29.69-59.05 \%, 56.45-66.63 \%, 2.62-4.05 \%$, $89.78-201.62 \%, 22.22-33.00 \%, 8.15-17.27 \%$, respectively. At the same time, values of lactic acid (LA), acetic acid (AA), butyric acid (BA) and propionic acid (PA), calcium (Ca), phosphor (P) and potassium (K) were $1.50-1.94 \%, 0.33-0.71 \%, 0.27-0.76 \%, 0.02-0.08 \%$; was $0.30-1.68 \%, 0.33-0.62 \%, 1.93-4.48 \%$, respectively. According to these results, it can be proposed that silages achieved from the $\mathrm{HV}+\mathrm{B}$ mixture have some superior properties for $\mathrm{CP}, \mathrm{ADF}, \mathrm{NDF}, \mathrm{RFV}, \mathrm{Ca}, \mathrm{P}$, and $\mathrm{K}$ compared with $\mathrm{HV}+\mathrm{W}$ mixtures.
\end{abstract}

Keywords: barley, chemical composition, Hungarian vetch, mixture rates, silage quality, wheat

\section{Introduction}

Turkey's Eastern Anatolia region which it is cold and snowy in winter and hot and dry in summer has a significant potential for animal breeding. As similar to other regions, Turkey, the pasture areas at Eastern Anatolia Region have noticeably declined as a result of excessive and uncontrolled grazing and the quality of pasture have decreased to the lowest levels. Because of this degradation of the pastures, a major decrease has occurred in the production of quality roughage and a quality. For this reason, to fodder forage crop cultivation, diversity the forage crops, produce alternative fodder crops and obtain silage from different fodder plants are quite important to overcome these problems.

In recent years, a considerable increase in silage production has become in Turkey. More than $80 \%$ of the total silage produced is corn silage (Alcicek and Karaayvaz, 2003). Corn, a hot climatic plant, can be effective in good maintenance and sufficient water conditions. The planting of silage corn at eastern Anatolia region or similar ecological places can appositely be affected from short period of vegetation and even sometimes spring and autumn frost damages. Therefore, Hungarian vetch is more 
resistant to cold and drought in comparison with vetch species, which it is grown and harvested without watering.

It can be said that silages of Hungarian vetch + barley mixtures have higher nutrition properties, because these crops contain both protein and carbohydrate. Thus, Miller (1984) reported that silages mixtures were more productive and quality when compared with pure ones. Lithourgidis et al. (2011) reported that environmental sources in mixed cultivation can more effectively be used and that it obtained the higher yields compared with pure sowing ones. Similarly, Tuna and Orak (2007) stated that the protein/carbohydrate ratio is better for silages obtained from these mixtures. In another study (Tas, 2002) it was reported that there was a lodging rate rising with an increase development of Hungarian vetch and for this reason it can be suggested that Hungarian vetch sowed mixing by wheat or triticale in winter sowings is better. In a study which investigated the effect of grass pea (Lathyrus sativus L.) and barley (Hordeum vulgare L.) on silage properties in Diyarbakır conditions (Seydosoglu and Gelir, 2019) was detected that $\mathrm{pH}$ and $\mathrm{DM}$ of silages at $100 \%$ of Grass pea and $100 \%$ barley were 3.994.09 and 28.28-32.98\%, respectively. Likewise, Saruhan et al. (2011) reported that DM, $\mathrm{CP}$ ratio and $\mathrm{pH}$ for mixtures of different levels of barley and birdsfoot trefol $(20,30$, $40,50,60,70 \%$ birdsfoot trefol $+80,70,60,50,40,30 \%$ barley) in same conditions of Diyarbakir were, respectively, 28.08-32.60\%, 10.08-12.20\% and 4.76-5.11.

Also, Koc et al. (1997) conducted to determine effect of microbial additive use in silages achieved form mixtures vetch (Vicia sativa L.) with cereal in laboratory conditions. In the study, the DM, pH, CP, NH3-N, LA, AA, BA of the this silages were $32.00-35.00 \%$; 3.70-3.65;11.15-10.01\%; 3.03-2.75 g/kg DM; 2.48-2.83\%; 0.40-0.40\%; $0.10-0.05 \%$, respectively, whereas these values showed an difference in field conditions (it were, respectively, $48.00-44.00 \% ; 3.86-4.59 ; 11: 37$ to $11: 49 \% ; 1.57-1.73 \mathrm{~g} / \mathrm{kg} \mathrm{DM}$; $3: 36$ to $3: 16 \% ; 0.63-0.42 \% ; 0.00-0.05 \%$ ). After the 56 days of silage harvested during flowering of vetch and at milk stage of barley, Polat et al. (1998) observed that $\mathrm{pH}, \mathrm{CP}$, LA and AA and ADF of the silages with control and Lactobacillus plantarum + Enterecoccus faecium groups were 4.40-4.37; 10.84-10.77\%; 2.25-2.38\%; 0.67$0.59 \%$; 65.20-65.20\%; 41.80-42.62\%.

Aykan and Saruhan (2018) conducted to determine the ensiled ability of silages achieved mixing by in different rates of barley and pea intercrops forage plants. In that study, $\mathrm{pH}$ value, DM, ADF, NDF, CP of these silages were 3.90-4.12, 19.23-30.98\%, $35.33-40.50 \%, 55.02-69.76 \%, 13.00-18.29 \%$, respectively. The dry matter, $\mathrm{CP}, \mathrm{pH}$ of silages obtained from different levels mixtures of white clover and barley were 27.53$31.38 \%, 10.17-13.63 \%$ and 5.05-5.34, respectively (Demirel et al., 2010). Bergen et al. (1991) reported that DM, pH, NDF ADF, LA and AA in the silages of wheat harvested at milk stage and dough stage after ensiling of 64 days were, respectively, 34.50$43.50 \%, 4.00-4.10,50.00-51.80 \%, 34.50-35.60 \%, 5.96-6.12 \%, 1.17-0.82 \%$. In some studies on silage it was indicated that propionic acid content of silage varied to type of silage or mixture (Homan, 2016; Seydosoglu, 2018).

In this study, it was aimed to determine the contents of organic acid, composition of some nutrient matter and values with quality of silages obtained from mixture Hungarian vetch with barley and wheat at different levels of mixture and thus to detect the best mixture ones. 


\section{Materials and methods}

This research was carried out at Mus city located at the Eastern Anatolia region, Turkey in 2017-2018 growing season (Fig. 1). As barley and wheat, the sowing of Hungarian vetch was made in winter season (3 November 2017). As material of plant, we used the Hungarian vetch which it is the most cultivated plant in Mus, Syrena (wheat), and Tokak 157/37 (barley) varieties. These varieties used are resistant to cold and drought and are recommended to Southern Marmara, Northern Inner and Aegean, Thrace, Black Sea, Southeast and Eastern Anatolia, Central Anatolia as well as Mediterranean Regions.

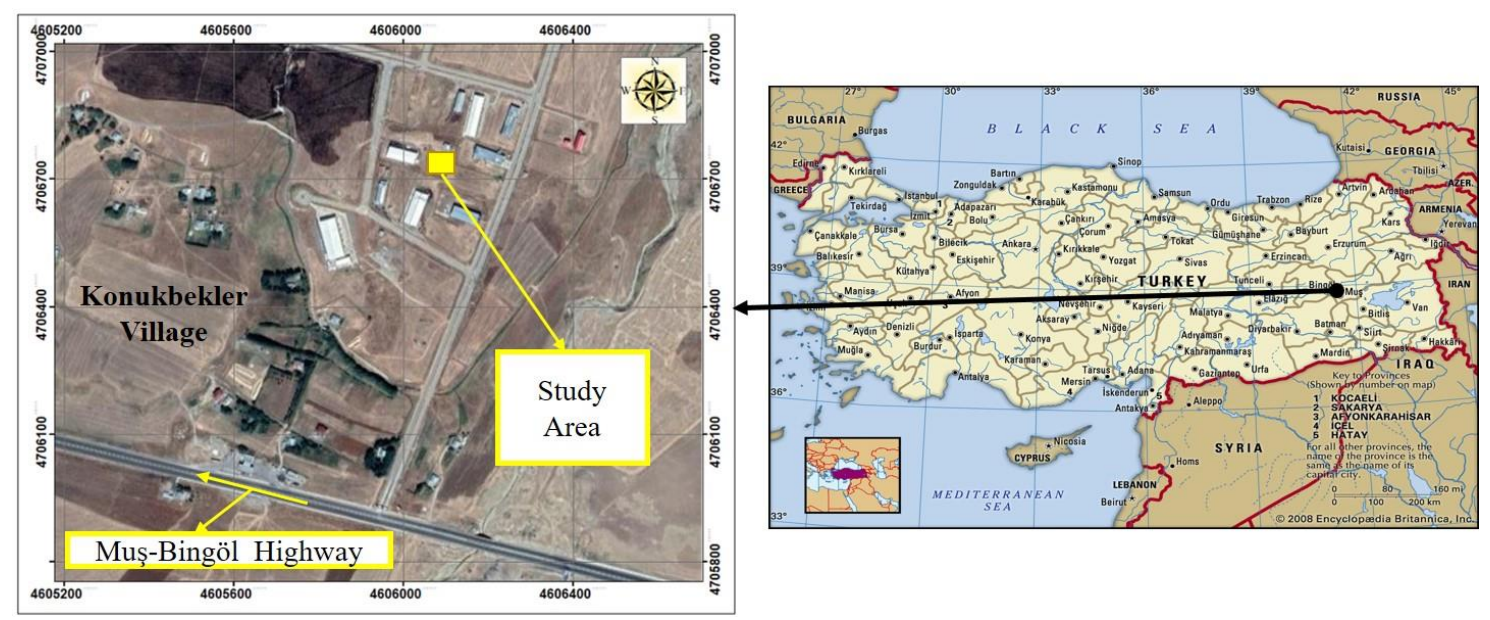

Figure 1. Location map of the study area

Each of these varieties was separately planted in 0.004 ha. $200 \mathrm{~kg} \mathrm{ha}^{-1}$ of barley and wheat, and $100 \mathrm{~kg} \mathrm{ha}^{-1}$ of Hungarian vetch were sowed. At the same time, $150 \mathrm{~kg} \mathrm{ha}^{-1}$ of DAP fertilizer $\left(27 \mathrm{~kg} \mathrm{ha}^{-1} \mathrm{~N}, 69 \mathrm{ha}^{-1} \mathrm{P}\right)$ were applied to barley and wheat during sowing; whereas it was $100 \mathrm{~kg} \mathrm{ha}^{-1} \mathrm{DAP}\left(18 \mathrm{~kg} \mathrm{ha}^{-1} \mathrm{~N}, \mathrm{ha}^{-1} \mathrm{P}\right)$ for Hungarian vetch.

Harvests were made in at full bloom for Hungarian vetch, at milking stage for barley and at heading stage for wheat (3 June 2018). The plots were separately simultaneously harvested with hand sickle. After the harvesting, material of silage was faded in the shade for 3-4 $\mathrm{h}$ and then cut into $0.5-1 \mathrm{~cm}$ dimensions with a silage harvester working with the tail shaft. After the chopping process, the materials were weighed on the sensitive scale according to the standardized rates.

The materials weighed were filled homogeneously and filled in 2-L plastic jars with 3 replications. The jars filled with silage materials are hand-tightened thoroughly. After the lid of the jars is closed tightly, they are wrapped with duct tape so that they do not breathe. It was then allowed to ferment into the dark environment for 60 days. At the end of this period, the maturing silages were opened and after the $4-5 \mathrm{~cm}$ part of the mouth of the jars were removed; the $\mathrm{pH}$ values were measured (Polan et al., 1998). After weighing $500 \mathrm{~g}$ of silage from each jar, it was dried to a constant weight for $48 \mathrm{~h}$ (AOAC, 1990) at $60^{\circ} \mathrm{C}$. After the dry weight of the silages was obtained, the samples were ground and prepared for analysis.

The content of crude protein $(\mathrm{CP})$, calcium $(\mathrm{Ca})$, magnesium $(\mathrm{Mg})$, phosphor $(\mathrm{P})$, potassium (K) content of silage, acid detergent fiber (ADF) and neutral detergent fiber (NDF) was determined with Near Infrared Reflectance Spectroscopy (NIRS), Near 
Infrared Analysis (NIR) by spectroscopic technique (Hoy et al., 2002), while organic acid ratios such as LA, AA, PA and BA were detected with HPLS (Canale et al., 1984).

The data obtained were analyzed to variance analysis by using JUMP program based on $5 \%$ and $1 \%$ of significance levels (SAS, 1998). The differences between the mean values were compared according to the LSD, multiple comparison tests (Gulumser et al., 2006). Digestible dry matter $[\mathrm{DDM}=88.9-(0.779 \times \mathrm{ADF} \%)]$ and dry matter consumption $(\mathrm{DMI}=120 / \mathrm{NDF} \%)$ and relative feed value from DDM and DMI ratios $[\mathrm{RFV}=(\mathrm{DDM} \mathrm{x}$ DMI)] were calculated from formulation described by Van Dyke and Anderson (2000).

\section{Climate characteristics of research area}

The average rainfall for many years in Mus province was $745.02 \mathrm{~mm}$, the relative humidity was $61.99 \%$, and the temperature was $8.10^{\circ} \mathrm{C}$. In planting period which relative humidity in January was highest, the temperature was low and rainfall was high (Table 1).

Table 1. Temperature, precipitation and relative humidity values of their search area*

\begin{tabular}{c|c|c|c|c|c|c}
\hline \multirow{2}{*}{ Months } & \multicolumn{2}{|c|}{ Temperature $\left({ }^{\circ} \mathbf{C}\right)$} & \multicolumn{2}{c|}{ Precipitation (mm) } & \multicolumn{2}{c}{ Relative humidity (\%) } \\
\cline { 2 - 7 } & LYA $^{* *}$ & $\mathbf{2 0 1 7}$ & LYA $^{* *}$ & $\mathbf{2 0 1 7}$ & LYA $^{* *}$ & $\mathbf{2 0 1 7}$ \\
\hline September & 21.13 & 22.90 & 20.16 & 0.00 & 32.76 & 20.50 \\
October & 13.54 & 12.80 & 65.87 & 34.40 & 53.12 & 41.70 \\
November & 5.56 & 6.00 & 65.24 & 69.60 & 67.91 & 70.80 \\
December & -1.62 & 1.30 & 99.36 & 33.30 & 80.23 & 75.40 \\
\hline Months & LYA** $^{* *}$ & $\mathbf{2 0 1 8}$ & LYA $^{* *}$ & $\mathbf{2 0 1 8}$ & LYA $^{* *}$ & $\mathbf{2 0 1 8}$ \\
\hline January & -5.25 & 0.50 & 113.30 & 84.00 & 82.09 & 76.40 \\
February & -2.87 & 4.10 & 86.69 & 81.30 & 77.90 & 64.30 \\
March & 3.78 & 9.40 & 104.27 & 61.40 & 67.56 & 54.70 \\
April & 10.58 & 12.50 & 90.63 & 26.80 & 57.90 & 46.70 \\
May & 15.28 & 15.40 & 69.22 & 125.60 & 57.42 & 63.40 \\
June & 20.91 & 20.50 & 30.28 & 48.80 & 43.02 & 48.60 \\
\hline Total/Average & 8.10 & 10.54 & 745.02 & 565.20 & 61.99 & 56.25 \\
\hline
\end{tabular}

*Meteorological Service of Mus. **LYA: Long years' average (2009-2018)

The temperature was above the average temperature during the growing season for a long time. However, relative humidity and rainfall was lower than the average of long years. The experiment area was harvested without required irrigation.

\section{Soil characteristics of research area}

Soil analysis of the experiment area was made in the soil analysis laboratory of private Mus. According to results of soil analyses of the experiment area, it was neutral, calcareous, salt-free and organic matter was low and also, the amount of phosphor is poor and potassium is sufficient (Table 2).

Table 2. Results of soil analysis of the search area*

\begin{tabular}{c|c|c|c|c|c}
\hline $\mathbf{p H}$ & $\begin{array}{c}\text { Salt } \\
\mathbf{d s} / \mathbf{m}\end{array}$ & $\begin{array}{c}\text { Lime }\left(\mathbf{C a C O}_{3}\right) \\
(\boldsymbol{\%})\end{array}$ & $\begin{array}{c}\text { Organic matter } \\
(\boldsymbol{\%})\end{array}$ & $\begin{array}{c}\mathbf{P}\left(\mathbf{P}_{2} \mathbf{O}_{\mathbf{5}}\right) \\
\mathbf{k g ~ h a}^{-\mathbf{1}}\end{array}$ & $\begin{array}{c}\mathbf{K}\left(\mathbf{K}_{2} \mathbf{O}\right) \\
\mathbf{p p m}\end{array}$ \\
\hline 7.02 & 0.02 & 1.58 & 1.14 & 26.30 & 209.99 \\
\hline
\end{tabular}

*Soil analysis were conducted at the Special Mus Soil Analysis Laboratory (2017) 


\section{Results and discussion}

\section{Content of ADF, NDF, DDM, DMI, RFV and DM}

In the present study we found that there were significant differences in silage mixtures achieved Hungarian vetch, barley and wheat for ADF, NDF, DDM, DMI, RFV and DM (P < 0.01) (Table 3).

Table 3. The mean values of silages for ADF, NDF, DDM, DMI, RFV and DM and groups

\begin{tabular}{|c|c|c|c|c|c|c|}
\hline Mixtures & ADF (\%) & NDF (\%) & DDM (\%) & DMI (\%) & RFV & DM (\%) \\
\hline $100 \% \mathrm{H}$ & $31.71 \mathrm{de}$ & $29.69^{f}$ & $64.19^{b}$ & $4.05^{\mathrm{a}}$ & $201.62^{\mathrm{a}}$ & $22.11^{f}$ \\
\hline $100 \% \mathrm{~B}$ & $28.57^{\mathrm{e}}$ & 32.91 ef & $66.63^{\mathrm{a}}$ & $3.65^{b c}$ & $188.66^{\mathrm{ab}}$ & $28.77^{\mathrm{c}}$ \\
\hline $100 \% \mathrm{~W}$ & $41.06^{\mathrm{ab}}$ & $59.05^{\mathrm{a}}$ & 56.91 de & $2.03^{\mathrm{g}}$ & $89.78^{f}$ & $33.00^{\mathrm{a}}$ \\
\hline $80 \% \mathrm{HV}+20 \% \mathrm{~B}$ & $37.88^{b c}$ & $30.87^{f}$ & $59.39^{\mathrm{cd}}$ & $3.88^{a b}$ & $178.98^{b c}$ & $22.22^{f}$ \\
\hline $60 \% \mathrm{HV}+40 \% \mathrm{~B}$ & $37.60^{b c}$ & 33.76 de & $59.60^{\mathrm{cd}}$ & $3.55^{\mathrm{bc}}$ & $164.23^{\mathrm{cd}}$ & $21.78^{f}$ \\
\hline $40 \% \mathrm{HV}+60 \% \mathrm{~B}$ & $35.95^{\mathrm{c}}$ & $36.11^{\text {de }}$ & $60.89^{c}$ & $3.32^{\mathrm{cd}}$ & $156.91^{\mathrm{d}}$ & $23.55^{\mathrm{e}}$ \\
\hline $20 \% \mathrm{HV}+80 \% \mathrm{~B}$ & $35.18^{\mathrm{cd}}$ & $37.81^{\mathrm{cd}}$ & $61.48^{b c}$ & 3.17 de & $151.40^{\mathrm{d}}$ & $24.88^{\mathrm{d}}$ \\
\hline $80 \% \mathrm{HV}+20 \% \mathrm{~W}$ & $36.04^{\mathrm{c}}$ & $36.47 \mathrm{de}$ & $60.81^{c}$ & $3.30^{\mathrm{cd}}$ & $155.90^{\mathrm{d}}$ & $23.55^{\mathrm{e}}$ \\
\hline $60 \% \mathrm{HV}+40 \% \mathrm{~W}$ & $40.72^{a b}$ & $42.19^{b c}$ & 57.17 de & 2.90 ef & $129.19^{\mathrm{e}}$ & $29.33^{c}$ \\
\hline $40 \% \mathrm{HV}+60 \% \mathrm{~W}$ & $41.65^{\mathrm{a}}$ & $45.87^{\mathrm{b}}$ & $56.44^{\mathrm{e}}$ & $2.62^{f}$ & $114.76^{\mathrm{e}}$ & $28.22^{c}$ \\
\hline $20 \% \mathrm{HV}+80 \% \mathrm{~W}$ & $41.65^{\mathrm{a}}$ & $46.14^{b}$ & $56.45^{\mathrm{e}}$ & $2.60^{f}$ & $113.80^{\mathrm{e}}$ & $31.33^{\mathrm{b}}$ \\
\hline Average & 37.09 & 39.17 & 60.00 & 3.19 & 149.57 & 26.25 \\
\hline $\mathrm{CV}(\%)$ & 5.62 & 6.96 & 2.72 & 6.96 & 8.23 & 2.85 \\
\hline LSD & $7.38^{* *}$ & $9.65^{* *}$ & $5.74^{* *}$ & $0.77^{\text {** }}$ & $43.61^{* *}$ & $2.64^{* *}$ \\
\hline
\end{tabular}

Values indicated by the same letters are not significantly different at the $5 \%$ level of significance, **P > 0.01. ADF: acid detergent fiber; NDF: neutral detergent fiber; DDM: digestible dry matter; DMI: dry matter intake; RFV: Relative Feed Value; DM: Dry matter

\section{$A D F$ and NDF ratio}

The rate of ADF of silages obtained from pure wheat and Hungarian vetch with wheat were higher than those of other mixture silages. Average ADF of these silages was $37.09 \%$, though the ADF values ranged in $28.57-41.65 \%$. According to the quality standards of legume, wheat and legume mixtures (Rohweder et al., 1978), ADF ratio of mixture silages obtained from wheat and Hungarian vetch (except $80 \% \mathrm{HV}+20 \% \mathrm{~W}$ ) was in the 3 grade quality class (41-42\%), whereas the silage obtained from barley and Hungarian vetch is in the 2 grade quality class (36-40\%) for ADF. In the current study, while The ADF content of the pure barley silage is in the top-quality class, Hungarian vetch silage is in the $1^{\text {st }}$ quality class. NDF ratios of mixture silages pure wheat silages with Hungarian vetch + wheat were higher than pure barley with Hungarian vetch + barley mixture silages. Average NDF of pure and mixture silages $39.17 \%$, though the ADF values ranged in $29.69-59.05 \%$. According to the quality standards of legume, wheat and legume mixtures (Rohweder et al., 1978), NDF of mixture silages obtained wheat with Hungarian vetch was in the $1^{\text {st }}$ quality class (40-46\%). Similarly, NDF of mixture silages achieved barley and Hungarian vetch was in the top-quality class (Tables 3 and 4).

There are many of studies on ADF and NDF rates of silage and findings of these studies Bergen et al. (1991) 34.50-35.60\%; Aykan and Saruhan (2018) 35.33-40.50\%; 


$$
-2800 \text { - }
$$

Polat et al. (1998) 41.80-42.62\% have changed at regular intervals. At the same time, rates of NDF were indicated by Bergen et al. (1991) 50.00-51.80\%; Aykan and Saruhan (2018) 55.02 - 69.76\% and Polat et al. (1998) 65.20-65.20\%.

Our findings for ADF and NDF in this study were different in some of the literature mentioned above. It is suggested that these differences between the findings can be resulted from the differences of plant species, periods, rations of mixture and ecological conditions.

Table 4. Quality standards for legume, wheat and legume mixtures (Rohweder et al., 1978)

\begin{tabular}{|c|c|c|c|c|c|c|}
\hline \multirow{2}{*}{ Standard of quality } & $\mathbf{C P}$ & ADF & NDF & \multirow{2}{*}{ DDM \% } & \multirow{2}{*}{$\begin{array}{c}\text { DMI } \\
\% \text { of BW }\end{array}$} & \multirow{2}{*}{ RFV } \\
\hline & \multicolumn{3}{|c|}{$\%$ of DM } & & & \\
\hline Prime & $>19$ & $<<31$ & $<<40$ & $>65$ & $>3.0$ & $>151$ \\
\hline 1 & $17-19$ & $31-35$ & $40-46$ & $62-65$ & $3.0-2.6$ & $151-125$ \\
\hline 2 & $14-16$ & $36-40$ & $47-53$ & $58-61$ & $2.5-2.3$ & $124-103$ \\
\hline 3 & $11-13$ & $41-42$ & $54-60$ & $56-57$ & $2.2-2.0$ & $102-87$ \\
\hline 4 & $8-10$ & $43-45$ & $61-65$ & $53-55$ & $1.9-1.8$ & $86-75$ \\
\hline 5 & $<<8$ & $>45$ & $>65$ & $<<53$ & $<<1.8$ & $<<75$ \\
\hline
\end{tabular}

\section{DDM (digestibility dry matter) ratio}

The mean DDM of the pure and mixture silages in this study was $60 \%$. DDM was the highest in pure barley silage with $66.63 \%$, whereas it was the lowest in mixture silages of $40 \% \mathrm{HV}+60 \% \mathrm{~W}(56.44 \%)$ and $20 \% \mathrm{HV}+80 \% \mathrm{~W}(56.45 \%)$ in the same group. The digestible dry matter (DDM) of pure barley silage was in the top-quality class, pure Hungarian vetch was in the first quality class and DDM of other pure and mixture silages were in the second quality class $(58-61 \%)$ based on the quality class described by Rohweder et al. (1978) (Tables 3 and 4).

\section{DMI (dry matter intake) ratio}

The mean DMI for all silages studied were $3.19 \%$ and the highest DMI were observed from mixture silages of $100 \% \mathrm{HV}(4.05 \%)$ and $80 \% \mathrm{HV}+20 \% \mathrm{~B}(3.88 \%)$, indicating that it is in the top-quality class based on the quality class described by Rohweder et al. (1978). The lowest DMI was observed in the pure wheat silage and it was in the $3^{\text {nd }}$ quality class, whereas mixture silages of Hungarian vetch and wheat at different mixing levels $60 \% \mathrm{HV}+40 \% \mathrm{~W}, 40 \% \mathrm{HV}+60 \% \mathrm{~W}, 20 \% \mathrm{HV}+80 \% \mathrm{~W}$ were in the second quality class based on the quality class described by Rohweder et al. (1978) (Tables 3 and 4).

\section{RFV (relative feed value)}

In the present study the mean RFV of pure and mixture silages was 149.57 . The highest RFV was founded at 100\% HV (201.62) and 100\% B (188.66) of silage in the same group and its quality class was the highest, while silage of pure wheat for RFV was in the $3^{\text {rd }}$ quality class according to quality criteria's Rohweder et al. (1978). Additionally, we observed that RFV of silage obtained from Hungarian vetch + barley mixture was higher than Hungarian vetch + wheat silage ones and it was better quality based on classification on quality (Tables 3 and 4). 


\section{DM (dry matter) ratio}

In the present study, the mean DM of silages was $26.25 \%$. The highest DM was achieved from pure wheat silages (33\%), whereas it was the lowest pure and the mixtures containing high Hungarian vetch with barley [80\% HV $+20 \%$ B $(22.22 \%)$; $60 \% \mathrm{HV}+40 \% \mathrm{~B}(21.78 \%)]$. Besides we detected that DM contains of mixture silages increase with increasing wheat.

The results of this study were different in findings reported in a several studies (Saruhan et al., 2011; Basaran et al., 2018; Aykan and Saruhan, 2018). These differences among studies mentioned above for DM of silage can be resulted from diverse harvesting periods or plant material of silage.

\section{Mineral matters and crude protein content}

In this present study, there were significant differences in calcium $(\mathrm{Ca})$, potassium $(\mathrm{K})$, phosphor $(\mathrm{P})$ and crude protein $(\mathrm{CP})$ contents of silages obtained from different mixture ratios of Hungarian vetch with barley and wheat $(\mathrm{P}<0.01)$ except for magnesium (Mg) (Table 5).

Table 5. The means of $C a, P, M g, K$ and $C P$ of mixture silages

\begin{tabular}{|c|c|c|c|c|c|}
\hline Mixtures & $\mathrm{Ca}(\%)$ & $\mathbf{P}(\%)$ & $\operatorname{Mg}(\%)$ & K $(\%)$ & CP $(\%)$ \\
\hline $100 \% \mathrm{H}$ & $1.68^{\mathrm{a}}$ & $0.57^{\mathrm{ab}}$ & 0.26 & $3.63^{b}$ & $17.27^{a}$ \\
\hline $100 \% \mathrm{~B}$ & $0.88^{\mathrm{e}}$ & $0.62^{\mathrm{a}}$ & 0.12 & $4.48^{\mathrm{a}}$ & $9.83^{\mathrm{e}}$ \\
\hline $100 \% \mathrm{~W}$ & $0.30^{f}$ & $0.33^{\mathrm{e}}$ & 0.23 & $4.47^{\mathrm{a}}$ & $8.15^{f}$ \\
\hline $80 \% \mathrm{HV}+20 \% \mathrm{~B}$ & $1.44^{\mathrm{b}}$ & $0.54^{b c}$ & 0.21 & $3.25^{b c}$ & $16.39^{a b}$ \\
\hline $60 \% \mathrm{HV}+40 \% \mathrm{~B}$ & $1.40^{\mathrm{b}}$ & $0.50^{\mathrm{c}}$ & 0.22 & $2.98 \mathrm{bd}$ & $16.56^{\mathrm{ab}}$ \\
\hline $40 \% \mathrm{HV}+60 \% \mathrm{~B}$ & $1.13^{\mathrm{cd}}$ & $0.50^{\mathrm{c}}$ & 0.21 & $2.96^{\mathrm{bd}}$ & $15.82^{\mathrm{ac}}$ \\
\hline $20 \% \mathrm{HV}+80 \% \mathrm{~B}$ & $0.98 \mathrm{de}$ & $0.58^{a b}$ & 0.19 & $3.05 \mathrm{bd}$ & $15.96^{\mathrm{ab}}$ \\
\hline $80 \% \mathrm{HV}+20 \% \mathrm{~W}$ & $1.23 \mathrm{bc}$ & $0.49^{c}$ & 0.22 & $2.90^{\text {ce }}$ & $14.35^{\mathrm{c}}$ \\
\hline $60 \% \mathrm{HV}+40 \% \mathrm{~W}$ & $1.14^{\mathrm{cd}}$ & $0.41^{\mathrm{d}}$ & 0.21 & $2.39 \mathrm{df}$ & $12.68^{\mathrm{d}}$ \\
\hline $40 \% \mathrm{HV}+60 \% \mathrm{~W}$ & $0.96^{\mathrm{de}}$ & $0.38^{\mathrm{de}}$ & 0.19 & $2.22^{\text {ef }}$ & $10.35^{\mathrm{e}}$ \\
\hline $20 \% \mathrm{HV}+80 \% \mathrm{~W}$ & $0.94^{\mathrm{de}}$ & $0.35^{\mathrm{de}}$ & 0.23 & $1.93^{\mathrm{f}}$ & $15.41^{\mathrm{bc}}$ \\
\hline Average & 1.10 & 0.48 & 0.21 & 3.12 & 13.89 \\
\hline $\mathrm{CV}(\%)$ & 12.34 & 8.51 & 16.72 & 12.88 & 6.54 \\
\hline LSD & $0.48^{* *}$ & $0.15^{* *}$ & $\mathrm{NS}$ & $1.41^{* *}$ & $3.20^{* *}$ \\
\hline
\end{tabular}

Values indicated by the same letters are not significantly different at the $1 \%$ level of significance, **P < 0.01 significant, NS: No significant, Ca: Calcium, P: Phosphor, Mg: Magnesium, K: Potassium, CP: Crude protein

Average $\mathrm{Ca}, \mathrm{P}, \mathrm{K}$ contents of silages was $1.10 \%, 0.48 \%$, and $3.12 \%$, respectively. The highest $\mathrm{Ca}$ was in the Hungarian vetch silage (1.68\%), but it was lowest in wheat silage $(0.30 \%)$. While silages of pure barley and Hungarian vetch and $20 \% \mathrm{HV}+80 \%$ $\mathrm{B}$ had the most $\mathrm{P}$ content, it was the lowest in pure wheat silage. The highest $\mathrm{K}$ content was found in pure barley and wheat silage in the same group. However, it was the lowest in $20 \% \mathrm{HV}+80 \% \mathrm{~W}$ mixture silage (Table 5). These elements are quite important in animal nutrition and animal rates should be contained at levels of $0.21 \% \mathrm{P}$, $0.65 \% \mathrm{~K}, 0.31 \% \mathrm{Ca}$ and $0.1 \% \mathrm{Mg}$ (Kidambi et al., 1989). 
According to these findings, when the mineral content of silages is evaluated; the mean $\mathrm{Ca}(1.10 \%), \mathrm{P}(0.48 \%), \mathrm{K}(3.12 \%)$ contents are above the amounts required to be in the feed rates of cattle and therefore there is no feeding problem in terms of the mentioned nutrients. In order to determine the yield and the quality of the mixture silages of Grass pea and Oat and Barley, Basaran et al. (2018) conducted a study. In that study, the highest of $\mathrm{K}(2.89 \%), \mathrm{Ca}(0.87 \%), \mathrm{P}(0.30 \%)$ were founded in the mixture ratio of $80 \% \mathrm{HV}+20 \% \mathrm{~B}$. We however, observed that our findings for these elements were higher than values reported by that study.

The CP values of silages analyzed were presented in Table 5. The average crude protein ranging from between $17.27 \%$ and $8.15 \%$ in silages studied was $0.89 \%$. It was observed that the CP content of the pure Hungarian vetch and Hungarian vetch + barley silages was higher than the $\mathrm{CP}$ content of the Hungarian vetch + wheat mixture silages.

Although the CP of pure wheat and barley silage was low (8.15-9.83\%, respectively), mixing of Hungarian vetch with wheat and barley improved the ratio of CP. The highest $\mathrm{CP}$ was obtained from pure Hungarian vetch (17.27\%) or silages of different mixing rates such as $80 \% \mathrm{HV}+20 \% \mathrm{~B}(16.39 \%) ; 60 \% \mathrm{HV}+40 \% \mathrm{~B}(16.56 \%) ; 40 \% \mathrm{HV}$ $+60 \%$ B (15.82\%); $20 \% \mathrm{HV}+80 \% \mathrm{~B}(15.96 \%)$ (Table 5). We found that there are differences for silage $\mathrm{CP}$ between the results reported by various researchers such as Polat et al. (1998) (10.84-10.77\%), Saruhan et al. (2011) (10.08-12.20\%), Seydosoglu (2019) (12.10-18.75\%), Aykan and Saruhan (2018) (13.00-18.29\%), Demirel et al. (2010) (10.17-13.63\%) and Polat et al. (1998) (10.84-10.77\%). Generally, our findings for pure or mixture silage CP were in accordance with literature for CP. Differences observed can be resulted from harvest periods and different plant species.

\section{pH and organic acid contents of silages}

In the present study we observed that there were significant differences in the $\mathrm{pH}$ values and ratios of organic acids of the silages obtained from the mixture silages achieved Hungarian vetch and barley and wheat in different ratios $(\mathrm{P}<0.01)$.

In this study, the $\mathrm{pH}$ values of the silages ranged from 3.76 to 4.08 , with an average $\mathrm{pH}$ of 3.90. Indicating differences in rates of mixture with barley, $\mathrm{pH}$ values of mixture Hungarian vetch with wheat was higher than mixture Hungarian vetch with barley ones. The highest $\mathrm{pH}$ was obtained from Hungarian vetch and barley mixtures in the same group. These groups were $80 \% \mathrm{HV}+20 \% \mathrm{~B}(3.99 \%), 60 \% \mathrm{HV}+40 \% \mathrm{~B}(4.08 \%), 40 \%$ $\mathrm{HV}+60 \% \mathrm{~B}(4.01 \%)$ and $20 \% \mathrm{HV}+80 \% \mathrm{~B}(3.99 \%)$.

Nonetheless, the $\mathrm{pH}$ of pure wheat silage was the lowest and also it was low in the other some groups such as $80 \% \mathrm{HV}+20 \% \mathrm{~W}(3.82 \%), 60 \% \mathrm{HV}+40 \% \mathrm{~W}(3.83 \%)$, $40 \% \mathrm{HV}+60 \% \mathrm{~W}(3.81 \%)$ and $20 \% \mathrm{HV}+80 \% \mathrm{~W}(3.81 \%)$. The authors reported that the most adequate of silage $\mathrm{pH}$ ranged from between 3.5 and 4.2. Our finding (3.764.08) for silage $\mathrm{pH}$ was in accordance with values of silage $\mathrm{pH}$ reported by these studies, showing that it was appropriate for nutrition quality (Kilic, 2006; Acikgoz et al., 2002; Aykan and Saruhan, 2018).

However, there were contrast with values of $\mathrm{pH}$ reported by Saruhan et al. (2011), Polat et al. (1998), Basaran et al. (2018), Demirel et al. (2010), Seydosoglu and Gelir (2019) and Bergen et al. (1991) and it was lower than in comparison with the results of these researches. The lactic acid (LA) values of the silages obtained mixed by at difference levels ranged from $1.50 \%$ to $1.94 \%$, with an average $\mathrm{pH}$ of $1.69 \%$. The highest LA was in the mixture group of $80 \% \mathrm{HV}+20 \% \mathrm{~W}(1.94 \%)$ and pure wheat 
$(1.80 \%)$, whereas it was the lowest. In mixture silages of $60 \% \mathrm{HV}+40 \% \mathrm{~B}(1.50 \%)$ and $20 \% \mathrm{HV}+80 \% \mathrm{~W}(1.50 \%)$ in the same group.

The acetic acid (AA) values of the silages ranged from $0.31 \%$ to $0.71 \%$, with an average $\mathrm{pH}$ of $0.49 \%$. The highest AA of pure Hungarian vetch, pure wheat and mixture of $20 \% \mathrm{HV}+80 \% \mathrm{~B}$ were $0.71 \%, 0.65 \%$ and $0.66 \%$, respectively. It was the lowest for mixture of $60 \% \mathrm{HV}+40 \% \mathrm{~B}(0.31 \%)$. The butyric acid (BA) values of the silages ranged from $0.27 \%$ to $0.76 \%$, with an average $\mathrm{pH}$ of $0.47 \%$. It was highest in the pure Hungarian vetch $(0.73 \%)$ and mixture of $80 \% \mathrm{HV}+20 \% \mathrm{~W}(0.76 \%)$. The propionic acid (PA) values of the silages ranged from $0.02 \%$ to $0.08 \%$, with an average $\mathrm{pH}$ of $0.06 \%$. The highest of propionic acid (PA) was obtained from mixtures of $80 \% \mathrm{HV}$ $+20 \% \mathrm{~W}$ and $60 \% \mathrm{HV}+40 \% \mathrm{~W}$ of silages (Table 6).

Table 6. The means of $p H, L A, A A, B A$ and $P A$ of mixture silages

\begin{tabular}{|c|c|c|c|c|c|}
\hline Mixtures & pH & LA (\%) & AA (\%) & BA $(\%)$ & PA (\%) \\
\hline $100 \% \mathrm{H}$ & $3.88^{\text {ce }}$ & $1.70^{b c}$ & $0.71^{\mathrm{a}}$ & $0.73^{\mathrm{a}}$ & $0.07^{b c}$ \\
\hline $100 \% \mathrm{~B}$ & $3.90 \mathrm{bd}$ & $1.69 \mathrm{bc}$ & $0.56^{\mathrm{b}}$ & $0.47^{\mathrm{c}}$ & $0.08^{a b}$ \\
\hline $100 \% \mathrm{~W}$ & $3.76^{\mathrm{e}}$ & $1.80^{\mathrm{ab}}$ & $0.65^{\mathrm{a}}$ & $0.35 \mathrm{de}$ & $0.02^{\mathrm{e}}$ \\
\hline $80 \% \mathrm{HV}+20 \% \mathrm{~B}$ & $3.99^{\mathrm{ab}}$ & $1.75^{\mathrm{b}}$ & $0.36^{\mathrm{eg}}$ & $0.52^{b c}$ & $0.07^{\mathrm{ab}}$ \\
\hline $60 \% \mathrm{HV}+40 \% \mathrm{~B}$ & $4.08^{\mathrm{a}}$ & $1.50^{\mathrm{d}}$ & $0.31^{\mathrm{g}}$ & $0.27^{\mathrm{f}}$ & $0.07^{a b}$ \\
\hline $40 \% \mathrm{HV}+60 \% \mathrm{~B}$ & $4.01^{\mathrm{ab}}$ & $1.59^{\mathrm{cd}}$ & $0.41^{\mathrm{de}}$ & $0.36^{\mathrm{d}}$ & $0.03^{\mathrm{e}}$ \\
\hline $20 \% \mathrm{HV}+80 \% \mathrm{~B}$ & $3.99^{\mathrm{ab}}$ & $1.71^{b c}$ & $0.66^{\mathrm{a}}$ & $0.55^{\mathrm{b}}$ & $0.03^{\mathrm{e}}$ \\
\hline $80 \% \mathrm{HV}+20 \% \mathrm{~W}$ & $3.82 \mathrm{de}$ & $1.94^{\mathrm{a}}$ & $0.46^{\mathrm{cd}}$ & $0.76^{\mathrm{a}}$ & $0.08^{\mathrm{a}}$ \\
\hline $60 \% \mathrm{HV}+40 \% \mathrm{~W}$ & $3.83 \mathrm{de}$ & $1.69^{b c}$ & $0.41^{\mathrm{df}}$ & $0.51^{\mathrm{bc}}$ & $0.08^{\mathrm{a}}$ \\
\hline $40 \% \mathrm{HV}+60 \% \mathrm{~W}$ & $3.81^{\mathrm{de}}$ & $1.67^{\mathrm{bc}}$ & $0.33^{\mathrm{fg}}$ & 0.30 ef & $0.05^{\mathrm{d}}$ \\
\hline $20 \% \mathrm{HV}+80 \% \mathrm{~W}$ & $3.81^{\mathrm{de}}$ & $1.50^{\mathrm{d}}$ & $0.53^{\mathrm{bc}}$ & $0.36^{\text {de }}$ & $0.06^{\mathrm{cd}}$ \\
\hline Average & 3.90 & 1.69 & 0.49 & 0.47 & 0.06 \\
\hline $\mathrm{CV}(\%)$ & 1.71 & 4.67 & 9.27 & 8.02 & 13.65 \\
\hline LSD & $0.23^{* *}$ & $0.27^{* *}$ & $0.16^{* *}$ & $0.12^{* *}$ & $0.02^{* *}$ \\
\hline
\end{tabular}

Values indicated by the same letters are not significantly different at the $1 \%$ level of significance, $* * \mathrm{P}<0.01$ significant, LA: lactic acid, AA: acetic acid, BA: butyric acid, PA: propionic acid.

According to some authors the butyric acid is not adequate for quality of silage and in general it has $0.1-0.6 \%$ of butyric acid (Woolford, 1984). By contrast, some researchers showed that there is a significant relationship between LA, AA and BA ratios with high quality of silage. According to these authors, LA ratio in these forages was above $2 \%$, whereas AA ratio must be between 0.3-0.7\% percent in type of these silages (McDonald et al., 1991; Alcicek and Ozkan, 1996). In this present study, it is observed that the LA ratio is lower than when compared with studies mentioned above, but ration of AA was normal. However, the amount of butyric acid was found to be higher than normal values in pure Hungarian vetch silage $(0.73 \%)$ and in mixtures of $80 \%$ of Hungarian vetch + wheat silages $(0.76 \%)$. However other groups of silages were normal for butyric acid (Table 6).

The insufficiency of homo-fermentative lactic acid bacteria (LAB) of the plant material used for silage leads to a delay in the decrease in $\mathrm{pH}$. Because of the insufficiency of LAB, an increase in the loss of nutrients and a decrease in the consumption of silages occur (Woolford, 1984). Therefore, in order to increase the 
lactic acid content in silages consisting of Hungarian vetch + wheat or Hungarian vetch + barley mixture, it is recommended to use various additives like Lactobacillus plantarum, which are homo fermantative. On the contrary, Kung et al. (2003) reported that the main ingredient used for legume silage in the USA is bacterial inoculants.

In current study, the findings with organic acids were lower than the results reported by Seydosoglu (2018) (2.01-2.16\%), Polat et al. (1998) (2.25-2.38\%) and Bergen et al. (1991) (5.96-6.12\%). However, our findings with AA, BA and PA showed differences in results reported by some authors (Bergen et al., 1991; Polat et al., 1998; Homan, 2016; Seydosoglu, 2018; Basaran et al., 2018).

\section{Conclusion}

In this present study it was conducted to determine the quality and chemical composition of the silage obtained by mixing Hungarian vetch with barley and wheat in different proportions, which they have same vegetation periods. At the same time, it was conducted to determine the quality and chemical composition of the silage obtained by mixing Hungarian vetch with barley and wheat in different proportions, which they have same vegetation periods. As a result, we observed that $\mathrm{CP}, \mathrm{Ca}, \mathrm{P}, \mathrm{K}$ and RFV of Hungarian vetch + wheat silages were higher than compared other groups of silages. Similarly, when the proportion of Hungarian vetch in mixing was increased, it also leads to an increase of $\mathrm{Ca}, \mathrm{P}, \mathrm{K}$ and RFV, DM and LA ratios of these silages. However, $\mathrm{ADF}$ and NDF ratios were lower in Hungarian vetch + barley silages.

\section{REFERENCES}

[1] Acikgoz, E., Turgut, İ., Filya, İ. (2002): Silage Plants Growing and Silage Making. Hasad Publishing, Istanbul (in Turkish).

[2] Alcicek, A., Karaayvaz, K. (2003): Use of corn silage in cattle feed. - Animalia 203: 6876 (in Turkish).

[3] Alcicek, A., Ozkan, K. (1996): Determination of milk acid, acetic acid and butyric acid by distillation in silage feeds. - Ege University, Journal of Agricultura Faculty 33(2-3): 191-198 (in Turkish).

[4] AOAC (1990): Official Methods of Analysis of the Association of Official Analytical Chemists. $15^{\text {th }}$ Ed. Vol. 1. - AOAC, Washington, DC.

[5] Aykan, Y., Saruhan, V. (2018): Determination of silage quality features of field pea (Pisum sativum L.) and barley (Hordeum vulgare L.) mixtures ensiling at different rates. - Dicle University, The Journal of Faculty of Veterinary Medicine 11(2): 64-70 (in Turkish).

[6] Basaran, U., Gulumser, E., Mut, H., Copur Dogrusoz, M. (2018): Determination of silage yield and quality of grasspea + cereal intercrops. - Turkish Journal of Agriculture - Food Science and Technology 6(9): 1237-1242 (in Turkish).

[7] Bergen, W. G., Byrem, T. M., Grand, A. L. (1991): Ensiling characteristics of whole-crop harvested at milk and dough stages. - J. Animal Sci. 69: 1766-1774.

[8] Canale, A., Valente, M. E., Ciotti, A. (1984): Determination of volatile carboxylic acids $\left(\mathrm{C}_{1}-\mathrm{C}_{5 \mathrm{i}}\right)$ and lactic acid in aqueous acid extracts of silage by high performance liquid chromatography. - J. Sci. Food. Agric 35(11): 1178-1182.

[9] Demirel, R., Saruhan, V., Baran, M. S., Andic, N., Senturk Demirel, D. (2010): Determination of different ratios of Trifolium repens and Hordeum vulgare mixtures on silage quality. - YYU J. AGR. SCI. 20 (1): 26-31 (in Turkish). 
[10] Gulumser, A., Bozoglu, H., Peksen, E. (2006): Research and Testing Methods. Ondokuz Mayis University, Faculty of Agriculture, Text Book (2. Press), Number: 48, Samsun.

[11] Homan, E. (2016): A study on determination of quality parameters of corn and soybean silages prepared with different mixing ratios. - MSc. Thesis. Yuzuncu Yil University, Institute of Natural and Applied Science, Van (in Turkish).

[12] Hoy, M. D., Moore, K. J., George, J. R., Brummer, E. C. (2002): Alfalfa yield and quality as influenced by establishment method. - Agronomy Journal 94:65-71.

[13] Kidambi, S. P., Matches, A. G., Gricgs, T. C. (1989): Variability for Ca, Mg, K, Cu, Zn and $\mathrm{K} /(\mathrm{Ca}+\mathrm{Mg})$ ratio among 3 wheat grasses and sainfoin on the southern high plains. Journal of Range Management 42: 316-322.

[14] Kilic, A. (2006): Determination of Quality in Forage. - Hasad Publishing, İstanbul (in Turkish).

[15] Koc, F., Ozduven, M. L., Yurtman, I. Y., Erman, S. M. (1997): A study on quality properties and use of microbial additives in vetch grain silage. - Hasad Journal 142: 3436.

[16] Kung, L., J. R., Stokes, M. R., Lin, C. J. (2003): Silage Additives. - In: Allen, M. et al. (eds.) Silage Science and Technology. Argon. Monogr. 42. ASA. CSSA, Madison, WI, pp. 305-360.

[17] Lithourgidis, A. S., Dordas, C. A., Damalas, C. A., Vlachostergios, D. N. (2011): Annual intercrops: an alternative pathway or sustainable agriculture. - Australian Journal of Crop Science 5(4): 396-410.

[18] McDonald, P., Henderson, A. R., Heron, S. J. E. (1991): The Biochemistry of Silage. 2nd Ed. - Chalcombe Publications, Aberystwyth.

[19] Miller, D. A. (1984): Forage Crops. - McGraw-Hill Book Company, New York.

[20] Polan, C. E., Stieve, D., Garrett, J. (1998): Protein preservation and ruminal degradation of ensiled forage treated with heat, formic acid, ammonia or microbial inoculant. Journal of Dairy Science 81: 765-776.

[21] Polat, C., Yurtman, I. Y., Koc, F., Coskuntuna, L., Ozduven, M. L. (1998): Use of microbial additives $1^{\text {st }}$ and $2^{\text {nd }}$ product effects on corn, vetch grain mixture, fermentation development and aerobic stability in sunflower silages. - Project Number: VHAG-1238, Tekirdag (in Turkish).

[22] Rohweder, D. A., Barnes, R. F., Jorgensen, N. (1978): Proposed hay grading standards based on laboratory analyses for evaluating quality. - Journal of Animal Science 47(3): 747-759.

[23] Saruhan, V., Demirel, R., Baran, M. S., Senturk Demirel, D. (2011): Determination of ensilage properties of different levels of Lotus corniculatus and Hordeum vulgare mixtures. - Anadolu J. Agr. Sci. 26(1): 40-45 (in Turkish).

[24] SAS (1982): User's Guide. - Statistical Analysis Systems. SAS, Cary, NC.

[25] Seydosoglu, S. (2018): Investigation of organic asic ratio of the effect of fodder pea (Pisum sativum L.) and barley (Hordeum vulgare L.) herbages mixed at different ratios. Anatolia the $1^{\text {st }}$ International Congress of Multidisciplinary Studies, 28-29 December, 893-898 (in Turkish).

[26] Seydosoglu, S. (2019): Investigation of the effect of fodder pea (Pisum sativum L.) and barley (Hordeum vulgare L.) herbages mixed at different rates on silage and feed quality. - Ege University, Journal of Agricultura Faculty 56 (3):297-302 (in Turkish).

[27] Seydosoglu, S., Gelir, G. (2019): A research on the silage properties of grass pea (Lathrus sativus L.) and barley (Hordeum vulgare L.) herbages mixed at different rates. - Igdir Univ. J. Inst. Sci. and Tech. 9(1): 397-406 (in Turkish).

[28] Tas, N. (2002): Determination of optimum mixture type, mixture rate and cutting time for vetch + wheat mixtures sown in spring and autumn under irrigated conditions. $-\mathrm{PhD}$. Thesis. Ataturk University, Institute of Natural and Applied Science, The Department of Field Crops, Erzurum (in Turkish). 
[29] Tuna, C., Orak, A. (2007): The role of intercropping on yield potential of common vetch (Vicia sativa L.)/oat (Avena sativa L.) cultivated in pure stand and mixtures. - Journal of Agricultural and Biological Science 2 (2): 14-19.

[30] Van Dyke, N. J., Anderson, P. M. (2000): Interpreting a Forage Analysis. - Alabama Cooperative Extension, Circular ANR-890.

[31] Woolford, M. K. (1984): The Silage Ferment. - Grassland Research Institute, Hurley. 